JURNAL SEKRETARIS DAN ADMINISTRASI BISNIS

Journal homepage: http://jurnal.asmtb.ac.id/index.php/jsab

Text Mining on Tourism Destinations in Bandung Raya (Case Study: Tangkuban Perahu and Kawah Putih)

\title{
Penambangan Teks Pada Tujuan Wisata di Bandung Raya (Studi Kasus: Tangkuban Perahu dan Kawah Putih)
}

\author{
1) Abdurrahman Rahim Thaha, ${ }^{2)}$ Fauzan Aziz \\ ${ }^{1,2)}$ Universitas Telkom \\ 1) abdurrahmanrahim@telkomuniversity.ac.id, ${ }^{2)}$ fauzanaziz@telkomuniversity.ac.id
}

\begin{tabular}{l} 
Article info \\
\hline Article history: \\
Received $10^{\text {th }}$ January 2020 \\
Received in revised form $19^{\text {th }}$ April 2020 \\
Accepted $17^{\text {th }}$ June 2020 \\
\\
Keywords: \\
tourism destination, \\
text mining, \\
review, \\
Bandung, \\
sentiment analysis
\end{tabular}

\begin{abstract}
The tourism sector occupies the fourth position as the largest foreign exchange earner for the country, amounting to the US \$20 billion. One of the three main tourist destinations in West Java is Bandung Raya with Tangkuban Perahu and Kawah Putih as nature theme destinations. One factor that drives the tourism industry to develop is tourist comfort. Tourist comfort can be seen from tourist online reviews on various travel sites. Review in traveling site can be used as a reference for tourists and provide feedback for stakeholders. One of the biggest travel review sites in the world is Trip Advisor.

The purpose of this study is to analyze the reviews on two nature-themed tourism destinations, Tangkuban Perahu and Kawah Putih, to obtain valuable information. This method uses text mining on all Englishlanguage reviews in the Trip Advisor site on tourism destinations. The steps are to collect data, preprocessing data, matrix term documents. The output consists of term frequency, word cloud and sentiment analysis with emotional classification.

Research findings illustrate that text mining can be applied to travel reviews for tourism destinations in Indonesia. Analysis result obtains tourist destination review ratings above the average that can still be improved, the frequency of tourist review filled with positive words even though expensive word appear, Ekman's emotional sentiment classification is dominated by emotional joy which means tourists feel comfortable in enjoying the tourism object, and emotional sentiment term frequency of sadness and anger can be stakeholder input for tourism destinations.
\end{abstract}




\section{Pendahuluan}

Pertumbuhan sektor pariwisata Indonesia tercatat berada di peringkat ke sembilan dunia. Data Kementerian Pariwisata tahun 2018 menunjukkan, sejak tahun 2013 sektor pariwisata menempati posisi keempat setelah minyak dan gas bumi, batubara, serta kelapa sawit sebagai penghasil devisa negara (indonesia.go.id, 2019). Kunjungan wisatawan mancanegara tahun 2019 menunjukkan peningkatan sebesar 4,86\% dibandingkan periode yang sama pada tahun 2018 (Kemenpar, 2019). Badan Pusat Statistik memperkirakan jumlah wisatawan mancanegara sepanjang tahun 2019 mencapai 16,3 juta kunjungan. Angka itu di bawah target yang ditetapkan Kementerian Pariwisata, yakni sebesar 18 juta kunjungan dengan target pendapatan devisa melebihi US \$ 20 miliar.

Badan Pusat Statistik menunjukkan provinsi Jawa Barat termasuk provinsi yang mengalami peningkatan kunjungan wisatawan mancanegara tahun 2019 sebesar 16,4\% dibandingkan periode yang sama pada tahun 2018. Pemerintah Jawa Barat mengembangkan tiga destinasi pariwisata utama. Ketiga destinasi itu yakni Kota Bandung dan sekitarnya, Geopark Ciletuh di Pelabuhanratu, dan Pantai Pangandaran (Bappeda Jabar, 2016). Kota Bandung dan sekitarnya atau disebut Bandung Raya memiliki beberapa macam destinasi pariwisata terkenal baik di tingkat lokal maupun mancanegara, akan tetapi melihat potensi yang dimiliki Jawa Barat, angka kunjungan wisatawan mancanegara masih dapat ditingkatkan.

Salah satu faktor yang dapat mendorong industri pariwisata nasional berkembang lebih cepat menurut Institute for Development of Economics and Finance (Indef) adalah kenyamanan wisatawan (Republika, 2019).

Tingkat kenyamanan suatu destinasi pariwisata dapat dilihat dari berbagai ulasan yang diberikan para wisatawan sebelumnya pada destinasi tersebut. Perkembangan teknologi informasi komunikasi yang masif membuat berbagai informasi dan data ulasan suatu tempat wisata dapat diakses dengan cepat. Informasi dan data di dunia maya dapat dijadikan acuan bagi para wisatawan mencari ulasan mengenai objek wisata yang dituju dan menjadi umpan balik untuk pemangku kepentingan terkait. Situs - situs traveling saat ini digunakan untuk mencari sumber ulasan objek wisata. Salah satu situs traveling yang menyediakan ulasan dari wisatawan mengenai pengalaman akomodasi, restoran dan objek wisata adalah Trip Advisor. Trip Advisor menjadi situs traveling terbesar di dunia dengan 390 juta pengunjung unik setiap bulan, 465 juta ulasan lebih dari tujuh juta akomodasi, restoran dan objek wisata di seluruh dunia (Valdivia, Luzón, \& Herrera, 2017). Trip Advisor menunjukkan objek wisata di Bandung Raya dengan ulasan terbanyak yaitu : Tangkuban Perahu, Jalan Braga, dan Kawah Putih. Berdasarkan tema wisata, Tangkuban Perahu dan Kawah Putih masuk kedalam kategori tema wisata alam dan pemandangan (Bappeda Jabar, 2016). Kedua objek wisata ini dapat dijadikan sumber data karena memiliki tema wisata yang sama.

Data ulasan di situs perjalanan online dapat diolah menjadi suatu informasi yang bermanfaat. Data ulasan dimanfaatkan untuk mengetahui kelebihan dan kekurangan suatu objek wisata sehingga diketahui permasalahan, pemecahan masalah dan eksplorasi peluang dari objek wisata. Dalam dunia bisnis, data ulasan dapat digunakan untuk menganalisis opini pelanggan tentang produk dan layanannya (Rozi, Pramono, \& Dahlan, 2013). Metode menganalisis data ulasan disebut text mining atau penambangan teks memanfaatkan data internet baik terstruktur atau tidak terstruktur.

Penelitian di Indonesia yang memanfaatkan data ulasan di internet pada objek wisata belum banyak. Pencarian kata kunci “text mining” pada Garba Rujukan Digital (Garuda) milik Kementerian Riset dan Teknologi menghasilkan 69 publikasi ilmiah, pencarian diakses tanggal 10 April 2020. Penelitian text mining pada Garuda kebanyakan dipakai untuk pengukuran efektifitas algoritma dan persepsi publik lewat media sosial. Dari 69 publikasi ilmiah hanya dua publikasi ilmiah yang masih terkait dengan pariwisata, dua penelitian ini melakukan text mining dengan objek hotel. Penelitian ini 
bertujuan untuk mengisi kekosongan ini dengan menyajikan analisis text mining ulasan wisatawan, mengenai objek wisata Bandung Raya di situs Trip Advisor. Penelitian ini juga menambah informasi tentang kualitas objek wisata seperti yang dirasakan oleh wisatawan.

Terakhir, temuan penelitian ini diharapkan dapat membantu pelanggan potensial dan industri pariwisata untuk mendapatkan wawasan dari ulasan ini secara efisien, untuk mengubah data berharga menjadi informasi bermanfaat yang dapat ditindaklanjuti.

\section{Tinjauan Pustaka/Literature Review \\ Ulasan Online}

Ulasan pelanggan untuk mengetahui tingkat kepuasaan merupakan tema penelitian yang banyak dilakukan berbagai disiplin ilmu termasuk teknik, manajemen, pemasaran dan hospitality (Chow \& Zhang, 2008). Secara tradisional, objek wisata melakukan wawancara langsung dan survey terhadap wisatawa untuk mendapatkan umpan balik wisatawan.

Tingkat pertumbuhan dan penetrasi internet membuat tiap orang dapat memberikan opini terhadap suatu objek secara cepat menggunakan sosial media, blog, forum diskusi maupun situs ulasan. Jumlah data teks yang banyak dapat dimanfaatkan organisasi untuk mencari pola, informasi, dan pengetahuan yang berharga. Organisasi dapat memakai pengetahuan berharga ini untuk pemasaran, posisi merk, pengembangan produk, dan kegiatan lainnya yang sesuai (Pang \& Lee, 2008).

Ulasan pengguna online membuat calon pengguna mengakses informasi yang lebih akurat dan terkini tentang produk / jasa. Rekomendasi berdasarkan pengalaman pengguna tidak hanya sebagai pilihan informasi perjalanan, tapi sumber paling berpengaruh terhadap keputusan perjalanan (Pan, MacLaurin, \& Crotts, 2007). Selain pengguna, manajemen juga dapat memanfaatkan ulasan online untuk melihat kekuatan dan kelamahan layanan lalu menjadikan bahan untuk manajemen hubungan pelanggan (Cho, Im, \& Hiltz, 2003).

\section{Text Mining}

Text mining adalah proses mengeksplorasi dan menganalisis sejumlah sejumlah besar data berbentuk teks tidak terstruktur agar dapat mengidentifikasi pola, informasi atau pengetahuan yang berguna (Efraim, 2011). Text mining disebut juga information extraction, text data mining, dan Knowledge Discovery in Databases (KDD) process (Hotho, Nürnberger, \& Paaß, 2005) berasal dari berbagai disiplin ilmu. Aktivitas umum pada text mining adalah kategorisasi teks, pengelompokan teks, concept/entity extraction, production of granular taxonomies, analisis sentimen, document summarization, dan entity relation modeling (Han, Pei, \& Kamber, 2011).

Perkembangan teknologi informasi yang cepat membuat pengembangan platform dan algoritma untuk menganalisis kumpulan data yang tidak terstruktur menjadi lebih mudah diterapkan. Berbagai organisasi menganalisis teks untuk menemukan potensi pengetahuan yang berharga dalam dokumen perusahaan, email, ulasan, sosial media dan sumber data berbasis teks lainnya. Salah satu penerapan text mining telah digunakan dalam bidang ulasan perjalanan untuk mengklasifikasikan ulasan pelanggan yang puas dan ulasan pelanggan yang tidak puas terhadap sebuah layanan (Berezina, Bilgihan, Cobanoglu, \& Okumus, 2016).

\section{Analisis Sentimen}

Analisis sentimen disebut juga opinion mining merupakan salah satu bidang dari Natural Language Processing (NLP) yang membangun sistem untuk mengenali dan mengekstrak opini dalam bentuk teks. Analisis sentimen banyak digunakan untuk menganalisis secara otomatis opini atau ulasan pelanggan tentang produk dan pelayanannya dalam dunia bisnis (Rozi et al., 2013). 
Informasi berbentuk teks saat ini banyak terdapat di internet dalam format forum, blog, media sosial, serta situs berisi ulasan. Analisis sentimen, mengolah informasi yang tadinya tidak terstruktur dapat diubah menjadi data yang lebih terstruktur untuk mendapatkan wawasan berharga.

Data tersebut dapat menjelaskan opini masyarakat mengenai produk, merk, layanan, politik, atau topik lainnya. Berbagai bidang memanfaatkan data-data tersebut untuk membuat analisis pemasaran, layanan masyarakat, ulasan produk, dan umpan-balik produk.

\section{Metodologi Penelitian}

Penelitian ini menerapkan text mining untuk menganalisis ulasan wisatawan pada situs ulasan. Text mining digunakan untuk mengesktrak informasi yang bermanfaat dari data tidak terstruktur berupa ulasan wisatawan. Gambar 1 menunjukkan metode yang dipakai dalam penelitian. Langkah awal dilakukan pengumpulan data ulasan dengan metode web scraping pada halaman situs Trip Advisor, selanjutnya dilakukan text mining yang menghasilkan keluaran berupa term frequency, word cloud, dan analisis sentimen.

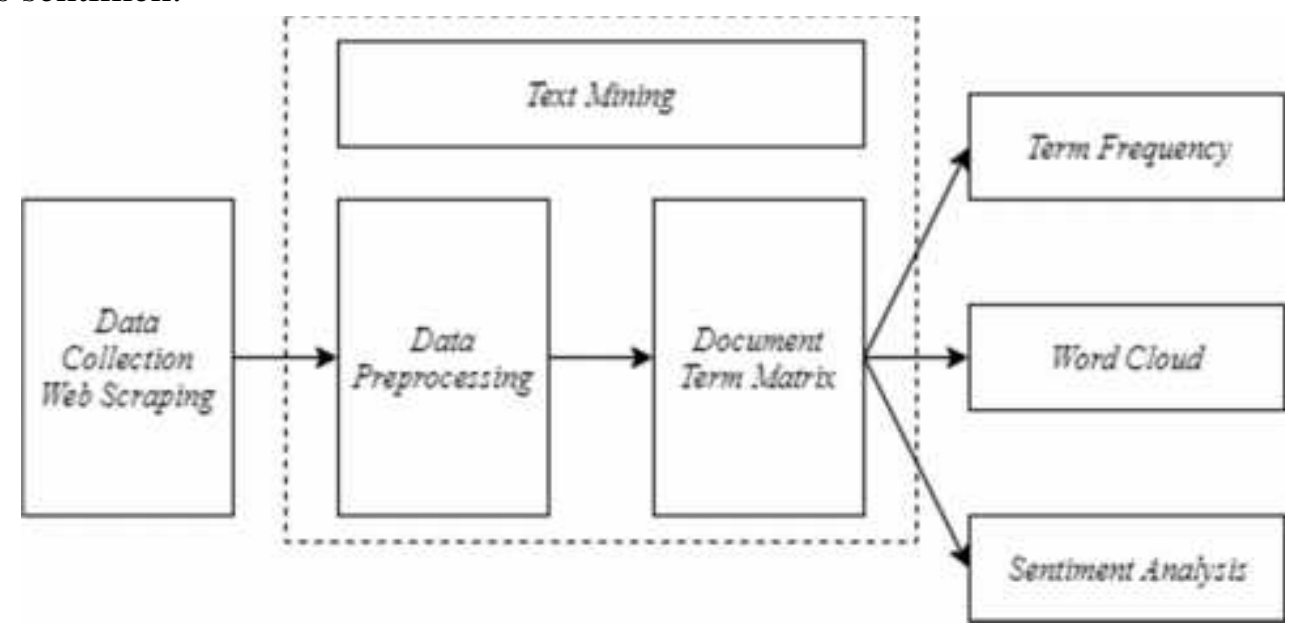

Gambar 1. Metode Penelitian

\section{Data Collection}

Data utama yang digunakan dalam penelitian adalah ulasan dari situs Trip Advisor berbahasa inggris untuk obyek wisata Tangkuban Perahu dan Kawah Putih. Ulasan ini diperoleh dengan melakukan teknik web scraping semua ulasan di situs Trip Advisor pada objek wisata Tangkuban Perahu dan Kawah Putih. Web scraping bekerja dengan cara mengekstrak data yang dibutuhkan dari suatu halaman situs. Web scraping mengektrak data secara otomatis sehingga mempermudah dan mempercepat pengambilan data di suatu situs dibanding melakukan metode copy paste secara manual.

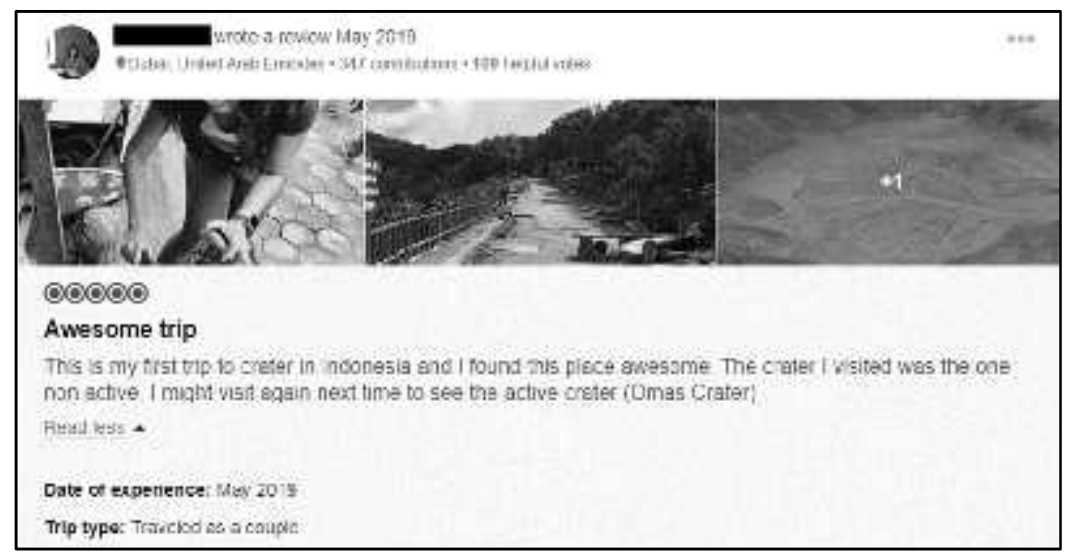

Gambar 2. Contoh Ulasan Situs Trip Advisor

Sumber: Situs Trip Advisor, 2020 
Gambar 2 merupakan contoh ulasan di situs Trip Advisor yang akan diekstrak dengan menggunakan web scraping. Hasil web sraping yang diekstrak yaitu: judul ulasan, isi ulasan, asal wisatawan yang melakukan ulasan, bulan dan tahun dilakukan ulasan, serta tipe perjalanan wisatawan (solo, dengan pasangan, dengan teman atau dengan keluarga). Hasil data ekstrak selanjutnya disatukan dalam satu file untuk dilakukan proses selanjutnya.

\section{Text Mining}

Text mining melakukan proses eksplorasi dan analisis sejumlah data collection untuk mengidentifikasi pola atau informasi yang bermanfaat. Proses text mining dapat disimpulkan dari dua fase, yaitu preprocessing dan integrasi data yang tidak terstruktur, serta statistik analisis data yang telah diproses untuk mengekstraksi konten dari teks (Hananto, 2015).

\section{Data Preprocessing}

Data ulasan yang diekstrak dari situs, masih berupa data mentah yang sebagian tidak terstruktur yaitu berbentuk kalimat teks. Data preprocessing dilakukan untuk membuat data mentah menjadi data yang berkualitas sehingga dapat diolah. Proses data preprocessing adalah data cleaning, data integration, data transformation, tokenization, normalization, dan filtering. Data cleaning digunakan untuk memperbaiki dan mengoreksi data yang tidak akurat atau tidak lengkap dengan format yang sesuai. Data integration merupakan proses penggabungan data dari berbagai sumber pada satu tempat data. Data transformation dilakukan untuk menyesuaikan skala dan format agar dapat dilakukan analisa data. Tokenization adalah proses membagi teks berupa, paragraf atau kalimat menjadi bagian - bagian kata yang disebut token. Normalization dipakai untuk memperbaiki kata - kata yang salah. Filtering merupakan proses penghilangan kata - kata dan tanda baca yang tidak bermakna secara signifikan.

\section{Document Term Matrix}

Document term matrix adalah matriks yang menggambarkan frekuensi kata, istilah atau token yang terjadi dalam kumpulan dokumen teks. Document term matrix akan menghitung jumlah kata yang muncul pada teks yang telah diolah.

\section{Term Frequency}

Term frequency (TF) adalah frekuensi kemunculan sebuah term dalam dokumen teks. Semakin besar jumlah kemunculan suatu term (TF tinggi) dalam dokumen teks, semakin besar juga nilai atau bobot sehingga memberikan nilai kesesuaian yang semakin besar.

\section{Word Cloud}

Word cloud adalah representasi visual dari data teks yang telah diolah. Word cloud biasanya digunakan untuk menggambarkan frekuensi kemunculan kata - kata pada suatu situs atau kumpulan dokumen teks. Word cloud bekerja dengan memvisualisasikan suatu bentuk teks secara bebas berbasis skala. Hasil term frequency akan digunakan untuk membangun word cloud.

\section{Analisis Sentimen}

Analisis sentimen pada penelitian ini menggunakan aplikasi open source Orange. Orange adalah alat dalam melakukan proses machine learning dan data mining untuk analisis data melalui bahasa pemrograman phyton dan pemrograman visual (Demšar et al., 2013). Orange memiliki fungsi analisis sentimen berupa keluaran kategori emosi dengan menghitung probabilitas atau skor emosi pada tiap ulasan berdasarkan data dari server untuk ditempatkan pada suatu kategori emosi.

Kategorisasi emosi yang populer dan telah digunakan sebelumnya oleh para peneliti dari NLP adalah klasifikasi emosi dari Paul Ekman. Paul Ekman mendefinisikan enam emosi dasar yang dapat dikenali secara universal yaitu: anger, disgust, fear, joy, sadness dan surprise (Colnerî̂ \& Demsar, 2018). Data tiap ulasan yang diproses selanjutnya akan dikategorisasi berdasarkan klasifikasi Paul Ekman. 


\section{Hasil dan Diskusi}

Data ulasan diambil dari situs Trip Advisor dari dua objek wisata yaitu Tangkuban Perahu dan Kawah Putih. Web scraping dilakukan pada semua ulasan berbahasa inggris dari ulasan awal sampai dengan ulasan terakhir di bulan Desember 2019. Data didapatkan sebanyak 1372 ulasan dari objek wisata Tangkuban Perahu dan 898 ulasan dari objek wisata Kawah Putih dengan total 2270 ulasan. Data ulasan yang diekstrak selanjutnya dilakukan data preprocessing dan term frequency. Hasil yang diperoleh dan digunakan dalam penelitian ini berupa rating ulasan, tipe perjalanan, negara asal dan judul ulasan.

Tabel 1. Rating Ulasan

\begin{tabular}{|l|l|l|}
\hline \multicolumn{2}{|c|}{ Rating } & Jumlah \\
\hline Excellent & 5 & 652 \\
\hline Good & 4 & 935 \\
\hline Average & 3 & 454 \\
\hline Poor & 2 & 112 \\
\hline Terrible & 1 & 117 \\
\hline Total & 2270 \\
\hline
\end{tabular}

Sumber: Data diolah Peneliti, 2020.

Rating merupakan bagian dari ulasan yang menggunakan bentuk simbol dalam mengekspresikan pendapat dari pengguna. Rating dapat diartikan sebagai penilaian dari para pengguna pada preferensi suatu objek terhadap pengalaman mereka. Rating merupakan salah salah satu faktor penting dan memiliki hubungan dengan minat pengguna (Farki \& Baihaqi, 2016).

Trip Advisor membuat lima kategori rating untuk ulasan pengunjung objek wisata. Rating dimulai dari angka satu sampai dengan lima yaitu: (1) Terrible, (2) Poor, (3) Average, (4) Very Good, dan (5) Excellent. Pengunjung objek wisata dapat memberikan ulasan beserta rating berdasarkan pengalaman pengunjung mulai dari rating satu sampai dengan lima.

Tabel 1 menunjukkan rating ulasan didominasi dengan rating nilai empat sebanyak 935 penilaian, rating nilai lima sebanyak 652 penilaian, rating nilai tiga sebanyak 454 penilaian, rating nilai dua sebanyak 112 penilaian, dan rating nilai satu sebanyak 117 penilaian. Rata - rata keseluruhan penilaian adalah 3,83, hal ini menunjukkan penilaian objek wisata Tangkuban Perahu dan Kawah Putih diatas rata - rata (average) dan hampir mendekati bagus (good). Nilai rata - rata penilaian yang belum mencapai diatas empat bisa ditingkatkan dengan memperbanyak ulasan dari para wisatawan yang memberikan rating nilai lima. Penilaian rating lima bisa didapatkan dengan menambahkan kenyamanan wisatawan agar memberikan nilai rating yang maksimal.

Tabel 2. Tipe Perjalanan Wisatawan

\begin{tabular}{|l|l|}
\hline Tipe Perjalanan & Jumlah \\
\hline Solo & 89 \\
\hline Pasangan & 331 \\
\hline Keluarga & 635 \\
\hline Teman & 525 \\
\hline Bisnis & 35 \\
\hline Tidak Terdefinisi & 655 \\
\hline Total & 2270 \\
\hline
\end{tabular}

Sumber: Data diolah Peneliti, 2020. 
Tipe perjalanan wisatawan ke objek wisata didominasi perjalanan dengan keluarga sebanyak 635 wisatawan, perjalanan dengan teman sebanyak 525 wisatawan, perjalanan dengan pasangan sebanyak 331 wisatawan, perjalanan solo 89 wisatawan, perjalanan bisnis 35 wisatawan, serta tipe perjalanan tidak terdefinisi dikarenakan tidak adanya info pada data ulasan sebesar 665 wisatawan. Data ini menunjukkan objek wisata masih banyak didatangi tipe wisatawan yang datang bersama - sama. Akses dan partisipasi wisatawan dengan tipe perjalanan solo harus ditingkatan. Tipe wisatawan perjalanan solo akan memberikan ulasan dan rating lebih tinggi dibandingkan tipe wisatawan yang datang bersama - sama (Radojevic, Stanisic, \& Stanic, 2015). Data statistik dari 2770 ulasan menunjukkan tipe wisatawan perjalanan solo dan bisnis memberikan rating nilai lima dan empat diatas 70 persen, sedangkan tipe wisatawan perjalanan bersama - sama (pasangan, keluarga, dan teman) memberikan rating nilai lima dan empat dibawah 70 persen.

Tabel 3. Negara Asal Wisatawan

\begin{tabular}{|l|l|}
\hline \multicolumn{1}{|c|}{ Negara Asal } & Jumlah \\
\hline Indonesia & 574 \\
\hline Singapura & 503 \\
\hline Malaysia & 486 \\
\hline Australia & 62 \\
\hline India & 43 \\
\hline United Kingdom & 34 \\
\hline Amerika Serikat & 32 \\
\hline Belanda & 29 \\
\hline Thailand & 18 \\
\hline Filipina & 14 \\
\hline Negara Lainnya & 149 \\
\hline Tidak Tedefinisi & 326 \\
\hline Total & 2270 \\
\hline
\end{tabular}

Sumber: Data diolah Peneliti, 2020.

Asal negara wisatawan terbanyak berasal dari wisatawan lokal atau asal Indonesia sebanyak 574 wisatawan, lalu diikuti wisatawan mancanegara asal Singapura sebanyak 503 wisatawan, Malaysia 486 wisatawan, Australia 62 wisatawan, India 43 wisatawan, United Kingdom 34 wisatawan, Amerika Serikat 32 wisatawan, Belanda 29 wisatawan, Thailand 18 wisatawan, Filipina 14 wisatawan, negara lainnya 149 wisatawan, dan yang tidak terdefinisi sebesar 326 wisatawan. Data tersebut menunjukkan wisatawan mancanegara masih didominasi oleh negara yang berbatasan langsung dengan Indonesia yaitu Malaysia dan Singapura diikuti negara dengan bahasa negara bahasa inggris seperti Australia, United Kingdom, dan Amerika Serikat.

Tabel 4. Term Frequency

\begin{tabular}{|c|l|c|}
\hline Num. & \multicolumn{1}{|c|}{ Term } & Freq. \\
\hline 1 & view & 361 \\
\hline 2 & place & 229 \\
\hline 3 & nice & 213 \\
\hline 4 & beautiful & 191 \\
\hline
\end{tabular}




\begin{tabular}{|c|l|c|}
\hline Num. & Term & Freq. \\
\hline 5 & crater & 162 \\
\hline 6 & visit & 152 \\
\hline 7 & great & 151 \\
\hline 8 & volcano & 132 \\
\hline 9 & bandung & 126 \\
\hline 10 & worth & 95 \\
\hline 11 & experience & 93 \\
\hline 12 & amazing & 91 \\
\hline 13 & good & 81 \\
\hline 14 & kawah & 81 \\
\hline 15 & must & 77 \\
\hline 16 & expensive & 75 \\
\hline 17 & tangkuban & 73 \\
\hline 18 & perahu & 68 \\
\hline 19 & nature & 63 \\
\hline 20 & putih & 60 \\
\hline 21 & scenery & 57 \\
\hline 22 & go & 42 \\
\hline 23 & see & 42 \\
\hline 24 & lake & 42 \\
\hline 25 & trip & 41 \\
\hline
\end{tabular}

Sumber: Data diolah Peneliti, 2020.

Tabel 4 merupakan 25 kata term frequency dengan frekuensi kemunculan tertinggi di semua judul ulasan yang telah diolah. Dari 25 kata pada tabel 4, term frequency didominasi oleh pengalaman wisatawan saat berada di objek wisata. Wisatawan cenderung menikmati objek wisata dengan munculnya kata - kata nice, beautiful, great, worth, amazing, dan good. Satu catatan adalah kata expensive yang menandakan kata dengan konotasi negatif dari wisatawan tentang masih mahalnya biaya objek wisata.

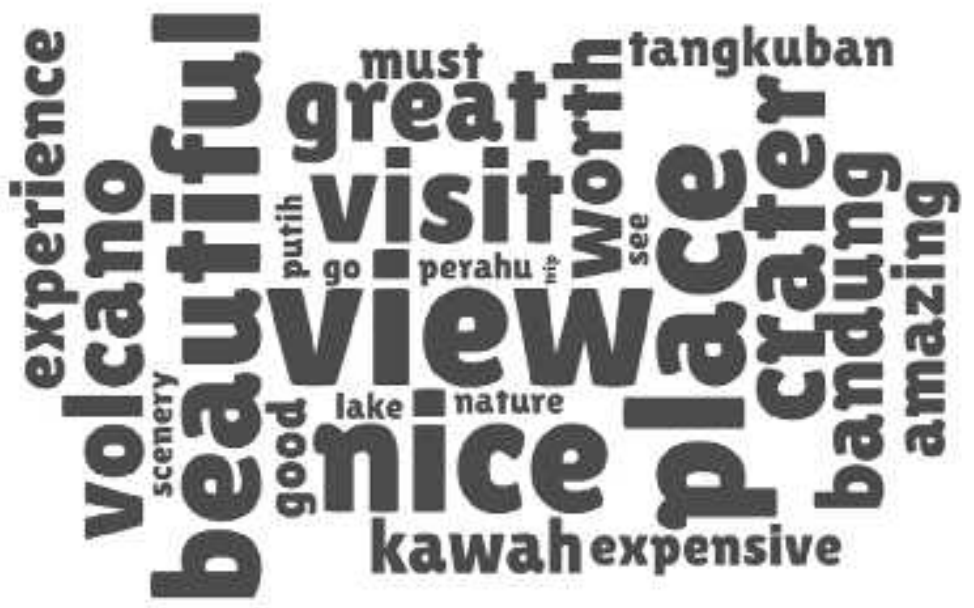

Gambar 3. Word cloud Tangkuban Perahu dan Kawah Putih Sumber: Data diolah peneliti, 2020. 
Gambar 3 menunjukkan word cloud dari term frequency. Word cloud memberikan kejelasan dalam mengidentifikasi tren dan pola yang jika dalam format tabel sulit dilihat karena besarnya jumlah data. Word cloud lebih mudah dipahami karena lebih menarik secara visual daripada format data tekstual (Kusumaningrum \& Adhy, 2018). Semakin besar kata-kata tersebut diwakili, semakin banyak kata yang muncul sehingga memudahkan visualisasi untuk memahami kata - kata relevan dari hasil ulasan.

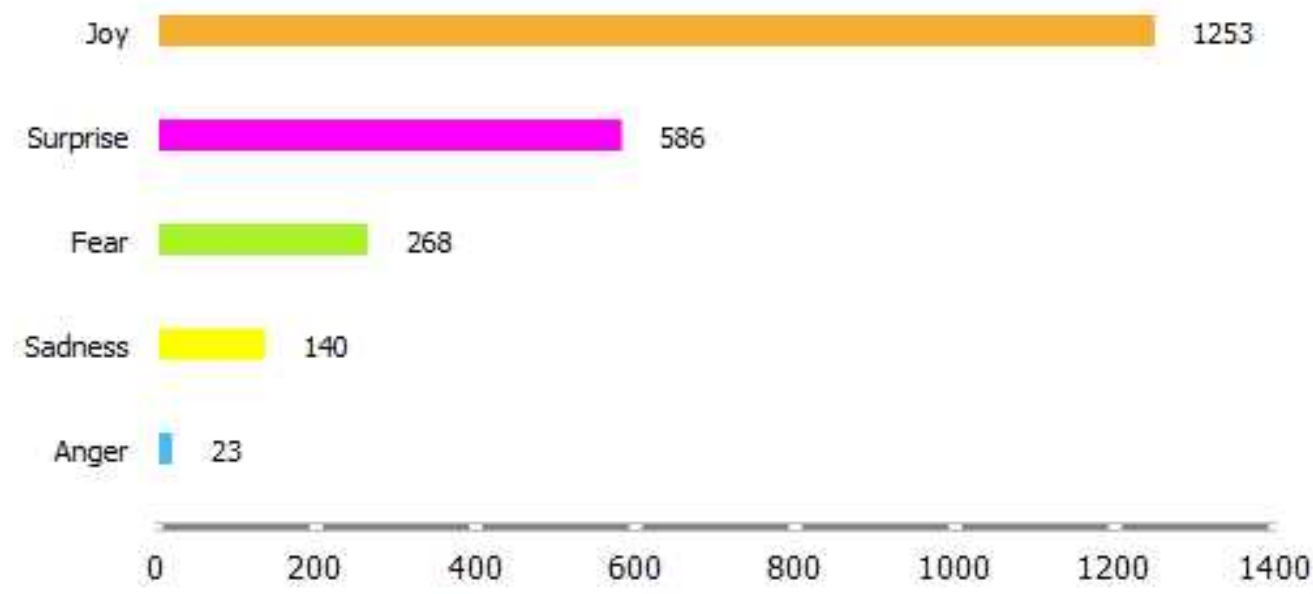

Gambar 4. Analisis Sentimen Profil Emosi Ekman

Sumber: Data diolah Peneliti, 2020.

Gambar 4 menunjukkan hasil klasifikasi profil emosi sentimen dari semua ulasan. Klasifikasi emosi Ekman bekerja dengan menghitung probabilitas atau skor emosi. Profil emosi yang dihasilan berupa anger, disgust, fear, joy, sadness dan surprise. Hasil analisis sentimen menunjukkan dominasi pada emosi joy yang berjumlah 1253 dari 2270 ulasan atau diatas 50 persen dari total ulasan. Profil emosi joy menunjukkan wisatawan menikmati objek wisata diikuti profil emosi surprise, fear, sadness, dan anger.

Tabel 5. Term Frequency tiap sentimen emosi

\begin{tabular}{|l|l|}
\hline \multicolumn{1}{|c|}{ Sentimen Emosi } & \multicolumn{1}{c|}{ Term } \\
\hline Joy & View, beautiful, place, great, crater \\
\hline Surprise & View, nice, visit, place, good \\
\hline Sadness & Expensive, place, rip, view, worth \\
\hline Fear & Crater, volcano, view, tangkuban, perahu \\
\hline Anger & Bad, management, view, smell, seller \\
\hline
\end{tabular}

Sumber: Data diolah Peneliti, 2020.

Keterbatasan kata - kata yang mengandung arti negatif pada term frequency di Tabel 4 bisa lebih di eksplorasi lebih dalam dengan melakukan proses term frequency ulasan per profil emosi. Ulasan dengan profil emosi tertentu difilter untuk selanjutnya dilakukan proses term frequency. Tabel 5 menunjukkan lima kata - kata dengan frekuensi kemunculan terbanyak pada ulasan tiap kategori emosi. Kategori emosi joy menunjukkan pengalaman menyenangkan dengan munculnya kata - kata beautiful dan great. Kategori emosi surprise diisi dengan kata - kata yang berkonotasi positif seperti nice dan good, hal ini menunjukkan profil emosi surprise muncul karena kepuasan wisatawan saat berada di objek wisata. Kategori emosi fear lebih ditujukan kepada bentuk objek wisata dibanding pengalaman terhadap lingkungan dengan munculnya kata - kata crater, volcano, tangkuban dan 
perahu, Term frequency kategori emosi sadness dan anger bisa menjadi masukan bagi pemangku kepentingan terkait perihal kata - kata negatif yang banyak muncul di dua kategori emosi ini.

\section{Simpulan}

Text mining telah digunakan sebagai metode baru di berbagai bidang. Di Indonesia, penggunaan text mining untuk objek wisata masih belum banyak digunakan. Penelitian ini menggunakan teknik web crawler dengan total 2770 ulasan di situs Trip Advisor pada objek wisata Tangkuban Perahu dan Kawah Putih yang merupakan objek wisata pemandangan alam di daerah Bandung Raya. Data ulasan yang terkumpul dilakukan analisis dengan text mining untuk mendapatkan informasi yang bermanfaat.

Keunikan penelitian ini terlihat dari tidak bergantungnya pada penggunaan data terstruktur untuk memahami persepsi wisatawan terhadap objek wisata yang biasa dilakukan dengan survey ke lapangan.

Penelitian ini menggambarkan isu - isu pada objek wisata baik pandangan positif maupun negatif wisatawan. Didapatkan analisis terkait rating objek wisata diatas rata - rata yang masih dapat ditingkatkan, term frequency wisatawan banyak diisi kata - kata positif walaupun muncul catatan kata expensive, klasifikasi sentimen emosi Ekman didominasi emosi joy yang berarti wisatawan nyaman menikmati objek wisata, dan term frequency dari sentimen emosi sadness dan anger dapat menjadi masukan pemangku kepentingan untuk objek wisata.

Penelitian ini memiliki keterbatasan yaitu sampel objek wisata yang terbatas pada dua objek wisata Tangkuban Perahu dan Kawah Putih serta kurang banyak kata - kata negatif yang ditemukan untuk eksplorasi sentimen negatif lebih mendalam.

\section{Arah Penelitian Masa Depan}

Penelitian ini dapat digunakan untuk menganalisis objek wisata lain dengan jangkauan dan jumlah objek wisata yang lebih banyak. Perbandingan tempat wisata di Indonesia dengan jumlah yang besar dan beragam dari berbagai tema dapat memperkaya wawasan pada penelitian. Sumber data bisa didapatkan dari beberapa situs ulasan dan sumber elektronik lain untuk mendapatkan data yang lebih banyak. Analisis sentimen bisa digunakan untuk menemukan perasaan wisatawan dan sebab naik turunnya jumlah kunjungan objek wisata sehingga dapat dipakai sebagai wawasan bagi pemangku kepentingan dalam meningkatkan kenyamanan objek wisata.

Penelitian kedepan dapat mempertimbangkan pendekatan sistem yang otomatis dan terintegrasi. Penelitian ini masih menggunakan campuran antara pekerjaan manual dan program komputer serta perangkat lunak yang berbeda - beda dalam menjalankan metode yang digunakan.

\section{Referensi}

Bappeda Jabar. (2016). Rencana Besar Pengembangan Destinasi Wisata Kelas Dunia Provinsi Jawa Barat.

Berezina, K., Bilgihan, A., Cobanoglu, C., \& Okumus, F. (2016). Understanding satisfied and dissatisfied hotel customers: text mining of online hotel reviews. Journal of Hospitality Marketing \& Management, 25(1), 1-24.

Calheiros, A. C. dos S. (2015). Sentiment analysis in hospitality using text mining: the case of a Portuguese eco-hotel.

Cho, Y., Im, I., \& Hiltz, R. (2003). The impact of e-services failures and customer complaints on electronic commerce customer relationship management. Journal of Consumer Satisfaction, Dissatisfaction and Complaining Behavior, 16, 106. 
Colneriĉ, N., \& Demsar, J. (2018). Emotion recognition on twitter: Comparative study and training a unison model. IEEE Transactions on Affective Computing.

Demšar, J., Curk, T., Erjavec, A., Gorup, Č., Hočevar, T., Milutinovič, M., ... Starič, A. (2013). Orange: data mining toolbox in Python. The Journal of Machine Learning Research, 14(1), 2349-2353.

Efraim, T. (2011). Decision support and business intelligence systems. Pearson Education India.

Farki, A., \& Baihaqi, I. (2016). Pengaruh Online Customer Review dan Rating Terhadap Kepercayaan dan Minat Pembelian pada Online Marketplace di Indonesia. Jurnal Teknik ITS, 5(2), A614-A619.

Han, J., Pei, J., \& Kamber, M. (2011). Data mining: concepts and techniques. Elsevier.

Hananto, A. (2015). Application of text mining to extract hotel attributes and construct perceptual map of five star hotels from online review: study of Jakarta and Singapore five-star hotels. ASEAN Marketing Journal, 7(2).

Hotho, A., Nürnberger, A., \& Paaß, G. (2005). A brief survey of text mining. In Ldv Forum (Vol. 20, pp. 19-62). Citeseer.

Kemenpar. (2019). Kementerian Pariwisata RI | Data Kunjungan Wisatawan Mancanegara Bulanan Tahun 2019. Retrieved January 6, 2020, from http://www.kemenpar.go.id/post/datakunjungan-wisatawan-mancanegara-bulanan-tahun-2019

Kusumaningrum, R., \& Adhy, S. (2018). WCLOUDVIZ: Word Cloud Visualization of Indonesian News Articles Classification Based on Latent Dirichlet Allocation. Telkomnika, 16(4).

Pan, B., MacLaurin, T., \& Crotts, J. C. (2007). Travel blogs and the implications for destination marketing. Journal of Travel Research, 46(1), 35-45.

Pang, B., \& Lee, L. (2008). Opinion mining and sentiment analysis. Foundations and Trends® in Information Retrieval, 2(1-2), 1-135.

Radojevic, T., Stanisic, N., \& Stanic, N. (2015). Solo travellers assign higher ratings than families: Examining customer satisfaction by demographic group. Tourism Management Perspectives, $16,247-258$.

Republika. (2019). Kenyamaan Wisatawan Faktor Pendorong Industri Pariwisata | Republika Online. Retrieved January 6, 2020, from https://republika.co.id/berita/q369xn383/kenyamaanwisatawan-faktor-pendorong-industri-pariwisata.

Rozi, I. F., Pramono, S. H., \& Dahlan, E. A. (2013). Implementasi Opinion Mining (Analisis Sentimen) untuk Ekstraksi Data Opini Publik pada Perguruan Tinggi. Jurnal EECCIS, 6(1), 37-43.

Valdivia, A., Luzón, M. V., \& Herrera, F. (2017). Sentiment analysis in tripadvisor. IEEE Intelligent Systems, 32(4), 72-77.

Wisata Indonesia di Mata Dunia | Indonesia.go.id. (2019). Retrieved January 6, 2020, from https://indonesia.go.id/ragam/pariwisata/pariwisata/wisata-indonesia-di-mata-dunia 